\title{
土地利用视角下城市交通事故 驱动机理的研究进展
}

\author{
王 成, 谢 波* \\ (武汉大学城市设计学院,武汉 430072)
}

\begin{abstract}
摘 要: 城镇化与机动交通的快速发展, 引发了城市土地利用与交通系统的重塑, 导致城市交通安全问题日益严 峻。为了优化土地利用布局并改善交通安全, 需要从土地利用视角开展交通事故的驱动机理研究。国内外该方面 研究形成了以交通流量和交通速度为主要中介因素联系土地利用与交通事故的经典理论框架, 却忽略了源于土地 利用并深刻影响交通安全的交通需求因素, 导致缺乏“土地利用一交通需求一交通事故”完整路径链的研究。论文 通过综述该领域文献, 在归纳总结城市交通事故影响因素的基础上, 揭示土地利用视角下交通事故的驱动机理并 探讨未来研究方向。研究指出, 土地利用的多维属性特征对交通事故具有重要影响, 土地利用与交通系统的动态 匹配关系及其对出行行为的影响是揭示交通事故驱动机理的关键突破口, 对于构建交通安全导向的城市土地利用 模式具有重要的理论与实践意义。
\end{abstract}

关 键 词: 交通事故; 土地利用; 驱动机理; 出行行为

交通事故是 21 世纪全球面临的重大挑战之一， 对城市居民安全产生了深远影响 [1]。随着城镇化与 机动交通的快速发展,过度依赖小汽车的发展模式 带来了城市交通流量与交通事故的快速增长, 交通 事故已超过艾滋病、肺结核、疮疾等疾病成为全球 第八大致残因素 ${ }^{[2]}$ 。据统计, 全球每年近 125 万人 死于交通事故,其中 $90 \%$ 的道路交通死亡发生在低 收人和中等收人国家 ${ }^{[3]}$ 。当前, 中国道路交通死亡 人数一直高居世界首位, 是导致过早死亡的第三大 原因,交通安全形势日益严峻 ${ }^{[4]}$ 。

城市交通事故受社会经济环境、个体条件、自 然环境、建成环境等多方面因素的影响, 土地利用 是其中的关键因素之一占了。改革开放以来, 随着中 国城镇化的快速发展, 城市用地发展经历了从“增 量发展”到“存量更新”的转变。“增量发展”时期, 以
扩张为代表的城市用地发展模式导致“推大饼”、土 地利用不集约、公共交通缺位、职住严重分离等问 题的产生, 使得居民出行距离与时间增加, 加剧了 交通生成与供给的矛盾,带来了交通流量的大规模 增长、交通拥堵等一系列问题[6] “存量更新” 时期, 以用地再开发、整治与维护为手段的城市更新,引 发土地利用要素及其所承载的人口密度、岗位数等 的变化, 不仅改变了交通系统的出行数量、出行方 式和结构、出行路径等要素, 而且还造成交通事故 时空分布的显著变化。

因此, 快速城镇化不仅带来机动交通的高速发 展, 而且导致城市土地利用与交通系统的重塑, 对 交通事故的发生与时空分布产生了重大影响。“十 三五”期间, 中国将“加强道路交通安全基础理论与 技术研究”列为道路交通安全规划的主要任务。面

收稿日期:2019-08-19;修订日期:2020-02-11。

基金项目: 国家自然科学基金项目(41971179); 教育部人文社会科学研究项目(17YJC840045)。[Foundation: National Natural Science Foundation of China, No. 41971179; Humanity and Social Science Foundation of Ministry of Education of China, No. 17YJC840045. ]

第一作者简介:王成(1985-), 男,湖北松滋人,博士生,主要从事城市交通系统规划研究。E-mail: traffic_wc@126.com *通信作者简介: 谢波(1983-), 男,湖北石首人,副教授,主要从事城市交通安全与土地利用规划研究。

E-mail: xiebo317@whu.edu.cn

引用格式: 王成, 谢波. 土地利用视角下城市交通事故驱动机理的研究进展 [J]. 地理科学进展, 2020, 39(9): 1597-1606. [Wang Cheng, Xie Bo Research progress on the driving mechanism of traffic accidents from the perspective of land use. Progress in Geography, 2020, 39(9): 1597-1606. ] DOI: 10.18306/dlkxjz.2020.09.016 
向经济发展、社会稳定和公共安全的多方面需求, 从多学科交叉视角开展城市交通事故的驱动机理 与规划调控研究十分必要。本文在分析国内外交 通事故前沿研究的基础上, 对城市交通事故的影响 因素进行总结, 并归纳城市土地利用对交通事故的 驱动机理与规划调控研究的主要内容与进展, 探讨 土地利用视角下交通事故驱动机理研究的发展方 向,进一步丰富和完善城市土地利用与交通事故关 系研究的理论体系。

\section{1 城市交通事故的影响因素研究}

交通事故受社会经济环境、个体条件、自然环 境、建成环境等方面因素的影响(表1), 呈现为类型 多样性、时空依赖性和空间异质性的特征 ${ }^{[7]}$ 。一方 面, 社会、经济、人口因素对交通事故具有显著影 响, 涉及人口结构、就业密度、经济收人、受教育程 度、驾驶人的年龄结构及性别结构等 ${ }^{[8]}$ 。研究指出, 儿童与老年人 ${ }^{[9-10]}$ 、贫困人口 ${ }^{[11]}$ 、教育水平较低的人 口 $^{[12]}$ 以及就业密度高的区域 ${ }^{[13]}$, 发生交通事故的风 险越高。另一方面, 城市自然环境和建成环境对交 通事故的产生具有决定性作用。首先, 自然环境方 面,天气因素和地形条件对交通事故具有重要影 响。研究指出, 雨雪天气 ${ }^{[14]}$ 、下午与夜晚时段 ${ }^{[7]} 、$ 坡 度 ${ }^{[15]}$ 与交通事故发生率正相关。其次, 建成环境方 面, 微观尺度以道路交叉口 ${ }^{[16]}$ 、地块出人口 ${ }^{[17]}$ 等为研 究对象, 宏观尺度主要以普查单元 ${ }^{[10]}$ 、交通小区 ${ }^{[18]}$ 等 为研究单元, 涉及的建成环境因素主要包括三方 面。第一, 道路交通环境包括城市道路密度、等级、 类型、交叉口形式和道路交通条件, 与交通事故密 切相关。例如, 城市道路里程和密度的增加会带来 严重交通事故数量的增加 ${ }^{[9,19]}$ 。城市交通事故发生 率与主次干道的密度正相关, 而与高速公路密度 负相关 ${ }^{[20]}$; 关于道路交叉口方面, 城市道路交叉口 越复杂, 步行与车行的冲突越多, 导致行人交通事 故越频发 ${ }^{[21]}$ 。而三叉路口的车速较低, 机动车与行 人的交通事故发生率较低 ${ }^{[8,22]}$ 。道路交通条件方面, 城市道路的人行道损坏程度与交通事故的发生率 正相关 ${ }^{[23]}$, 缺乏公共交通的城市干道也会增加机动 车与行人的交通事故率 ${ }^{[10]}$ 。第二, 设施可达性与交 通事故显著相关 ${ }^{[24]}$, 主要原因在于目的地吸引了 邻近区域大量交通流量和行人活动, 而且设施的 密度相比于邻近程度对行人与机动车交通事故的 影响更大 ${ }^{[25]}$ 。例如, 公交站点密度与交通事故正相
表 1 交通事故的影响因素

Tab.1 Influencing factors of traffic accidents

\begin{tabular}{|c|c|c|}
\hline 类型 & 影响因素 & 作用方式 \\
\hline \multirow[t]{5}{*}{ 社会经济特征 } & 人口密度 & 影响行人活动与暴露程度 \\
\hline & 年龄结构 & 影响行人的暴露程度 \\
\hline & 就业密度 & $\begin{array}{l}\text { 影响通勤人口的活动与暴露 } \\
\text { 程度 }\end{array}$ \\
\hline & 经济收人 & 决定机动车数量 \\
\hline & 教育水平 & 影响行人一机动车接触概率 \\
\hline \multirow[t]{6}{*}{ 自然环境 } & 天气 & 影响机动车驾驶人的警觉性 \\
\hline & 湿度 & 影响机动车驾驶人的警觉性 \\
\hline & 温度 & 影响机动车驾驶人的警觉性 \\
\hline & 坡度 & 决定步行难度 \\
\hline & & 影响行人一机动车冲突 \\
\hline & 时段 & 影响行人一机动车接触概率 \\
\hline \multirow[t]{6}{*}{ 道路交通条件 } & 行车道数量 & 影响行人暴露程度 \\
\hline & 路肩宽度 & 影响行人暴露程度 \\
\hline & 道路网密度 & 影响机动车一行人接触概率 \\
\hline & 停车场密度 & 决定机动车的停靠次数 \\
\hline & & 影响人和机动车的接触 \\
\hline & 交叉口密度 & 影响机动车一行人接触概率 \\
\hline \multirow[t]{4}{*}{ 设施可达性 } & 公交车站密度 & 影响行人一机动车的冲突 \\
\hline & 零售业密度 & 影响机动车一行人接触概率 \\
\hline & 商务办公密度 & 影响机动车一行人接触概率 \\
\hline & 学校密度 & 影响机动车一行人接触概率 \\
\hline \multirow[t]{7}{*}{ 土地利用特征 } & 居住用地 & 影响机动车一行人接触概率 \\
\hline & 商业用地 & 影响行人暴露程度 \\
\hline & 工业用地 & 影响行人暴露程度 \\
\hline & 教育用地 & 影响行人一机动车接触概率 \\
\hline & 宗教用地 & 影响行人一机动车接触概率 \\
\hline & 土地利用混合度 & 影响行人一机动车接触概率 \\
\hline & 土地利用强度 & 影响行人暴露程度 \\
\hline
\end{tabular}

关 ${ }^{[26]}$, 学校密度与步行、自行车交通事故正相关 ${ }^{[27]}$ 。 此外, 研究发现, 商业与办公设施, 例如零售店 ${ }^{[28]}$ 、 大型商业体 ${ }^{[8]}$ 以及社区商业中心密度 ${ }^{[29}$ 对自行车、 行人和机动车交通事故均具有显著影响。第三,城 市土地利用对交通事故的产生具有重要作用, 微观 层面包括土地利用类型、强度,宏观层面包括土地 利用形态与模式 ${ }^{[10,30-31]}$ 。

\section{2 城市土地利用对交通事故的驱动机 理研究}

从土地利用视角开展交通事故的影响因素和 驱动机理研究是当前地理学、交通工程学和城市规 划学等交叉学科领域关注的热点,其基础理论与方 法体系还涉及公共安全学、社会学等多个领域, 本 
文在解析影响交通事故的土地利用因素基础上,归 纳总结城市土地利用对交通事故的作用机理。

\section{1 影响交通事故的土地利用因素}

\subsection{1 土地利用类型与强度}

不同土地利用类型对交通事故的影响存在差 异性。首先, 商业用地 ${ }^{[24]}$ 和公共服务设施用地 ${ }^{[18]}$ 对 交通事故具有正向影响。其次, 绿地 ${ }^{[32}$ 和娱乐休闲 用地 ${ }^{[33]}$ 对机动车与行人交通事故具有负向影响。 然而, 关于教育用地、居住用地、工业用地对交通事 故的影响存在不一致的结论。教育用地方面, 学校 数量越多, 越会带来集中的交通流量和交通事故风 险暴露 ${ }^{[34]}$; 而Moudon 等 ${ }^{[29]}$ 认为教育用地会采取更多 的交通干预措施和限速管理, 从而降低机动车与行 人的交通事故风险。居住用地方面,普遍认为该类 用地具有更低的限速, 以及在工作时间更少的行人 流量, 从而降低了交通事故风险 ${ }^{[35]}$; 而另一部分学 者认为居住用地的人口密集, 增加了通勤时间以外 居住区内部的行人流量, 提升了行人与自行车交通 事故的风险 ${ }^{[13]}$ 。工业用地方面, 作为行人不友好的 区域,工业用地的行人流量会少于其他类型的用 地, 从而降低了机动车与行人交通事故的风险 ${ }^{[15]}$; 而Ukkusuri 等 ${ }^{[21]}$ 认为工业用地内汽车限速通常较高 且货车较多,增加了行人交通事故的风险。同时, 不同的用地类型产生的交通事故类型也存在差 异。例如, 机动车与机动车交通事故在商业与工业 用地的风险最高, 而机动车与行人的交通事故在酒 店用地的风险最高 ${ }^{[36]}$ 。

另一方面, 土地利用强度会影响区域内行人和 机动车的流量大小与行为模式 ${ }^{[37]}$ 。高强度土地开 发会增加区域内行人和机动车交通的吸引量, 但高 密度与高混合的土地利用方式能够减少机动车出 行率与交通流量 ${ }^{[38]}$, 从而降低交通事故发生率; 而 低密度的土地利用会带来交通事故数量与死亡率 的上升 ${ }^{[39]}$ 。

\subsection{2 土地利用形态与模式}

关于土地利用形态方面, 研究指出, 分散的土 地利用形态导致长距离交通出行, 并增加机动车交 通流量 ${ }^{[40]}$ 。城市蔓延引发了更高的交通速度与更 多的机动车出行里程, 对机动车与行人交通事故具 有直接的正向影响 ${ }^{[41]}$ 。而紧凑的城市用地形态降 低了交通速度, 减少了严重机动车交通事故的发生 率 ${ }^{[22]}$, 城市紧凑指数每增加 $1 \%$, 交通事故将减少 $1.49 \%$, 行人交通事故将降低 $1.47 \%{ }^{[43]}$ 。因此, 紧凑
的土地利用结构有利于降低交通事故发生率和严 重程度。

关于土地利用模式方面, 土地利用混合度与交 通事故呈正相关。土地利用混合度高的区域, 其使 用功能更为多样化, 导致人流量增多, 产生机动车与 自行车交通冲突的概率更高 ${ }^{[4]}$, 增加了行人与自行 车事故的发生率 ${ }^{[45]}$ 。具体到各类用地混合方面, 商 业和居住用地的混合模式会增加行人交通事故 ${ }^{[10]}$, 高强度的商业一居住用地混合模式也会增加交通 事故发生率 ${ }^{[46]}$, 然而用地的平衡发展能够减弱行人 交通事故的严重程度 ${ }^{[4]}$ 。

\section{2 城市土地利用对交通事故的作用机理}

土地利用是建成环境的重要组成要素,其对交 通事故的作用机理遵循城市建成环境与交通事故 关系的理论框架(图 1), 交通流量、交通速度和交通 冲突发挥着关键中介作用 ${ }^{[48-49]}$ 。一方面, 交通流量 与交通事故率和严重程度密切相关, 年平均日交通 流量(Annual Average Daily Traffic, AADT)与车辆里 程(Vehicle Miles Traveled,VMT)是衡量交通流量的 2 个重要指标。另一方面, 交通速度是影响交通事 故严重程度的重要因素 ${ }^{[22]}$, 车速越快使得人们对于 交通事故风险的响应时间越短 ${ }^{[0]}$, 行人与自行车较 低的运行速度与机动车流的速度差异也增加了交 通事故的发生率 ${ }^{[1]}$ 。交通冲突方面, 主要从微观层 面分析停车空间、交叉口、行人空间等地点存在的 交通事故暴露风险 ${ }^{[48]}$ 。

关于不同类型交通事故的驱动机理,主要涉及 机动车一机动车、机动车一行人或自行车、行人一非 机动车等方面, 交通流量和交通速度依然为主要中 介因素,但其发挥的作用和影响程度呈现差异性。 例如, 行人交通事故方面, 机动车交通速度对重大 行人交通事故具有显著的正向影响,而交通流量次 $之^{[52-53]}$ 。同时,也有研究指出, 交通流量越大, 重大行

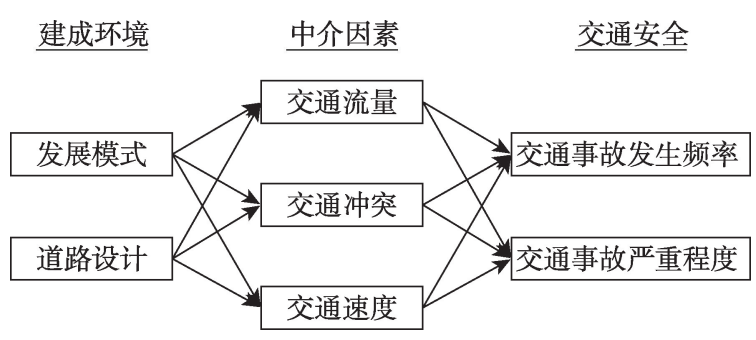

图 1 城市建成环境与交通事故关系的理论框架 ${ }^{[48]}$

Fig.1 A theoretical framework of the relationship between the built environment and traffic accidents ${ }^{[48]}$ 
人交通事故的发生率越低 ${ }^{[54]}$; 自行车交通事故方面, 机动车速度与自行车交通事故的发生率和严重程度 密切相关 ${ }^{[55]}$, 而且自行车行驶里程是联系建成环境 与“自行车一机动车”交通事故的主要中介因素 ${ }^{[6]}$, 它对该类交通事故的影响程度相比于机动车行驶 里程更大 ${ }^{[57]}$; 机动车交通事故方面, 机动车交通流 量主要影响交通事故的发生率, 而交通速度主要影 响交通事故的严重程度 ${ }^{[4]}$ 。总体而言, 城市建成环 境对交通事故具有重要影响, 交通流量与交通速度 是联系两者的主要中介因素。对于不同类型的交 通事故而言, 不仅建成环境的影响因素有所不同, 而且中介因素的效应也呈现差异性。相比于机动 车交通事故, 交通速度对于行人与自行车交通事故 的中介效应更为显著。

\section{3 出行行为视角下城市土地利用对交通事故的 影响}

现有关于城市土地利用对交通事故作用机理 的研究, 构建了 “土地利用一交通流量与速度一交通 事故” 的理论框架 ${ }^{[58]}$ 。然而, 交通事故实质上是交 通需求与交通供给矛盾的体现, 土地利用与交通系 统的动态匹配关系及其对出行行为多维度属性的 影响, 是揭示交通事故驱动机理的关键突破口 ${ }^{[48]}$ 。 城市区域性出行行为的多维度属性特征(包括出行 量、出行时间、出行距离、出行方式和出行分布等) 影响了城市宏中观层面交通事故的发生规律 ${ }^{[59]}$, 而 区域性出行行为的塑造主要依赖于土地利用与交 通系统的协同作用。城市土地利用作为群体出行 行为的宏观发生器, 即区域交通需求的源头, 通过 影响出行行为(出行流量、方式与分布)而对城市交 通系统产生作用(图2), 进而间接影响交通事故的发 生率与严重程度 ${ }^{[00]}$ 。因此, 出行行为特征反映了群 体对于交通供给的需要(交通需求), 它在土地利用 与交通事故的关系中扮演着重要连接作用。然而, 现有研究主要探讨“土地利用与交通需求” 和“土地 利用与交通事故”的关系框架, 缺乏“土地利用一交 通需求(出行行为)一交通事故” 的完整路径链的研 究框架。

传统的交通四阶段模型(包括交通生成、交通 分布、出行方式选择、交通分配 4 个阶段)将土地利 用作为影响交通需求、塑造出行行为时空分布的主 要因素之一, 通过整合区位活动与交通活动、预测 交通需求特征, 从出行行为视角揭示土地利用与交 通系统的关系 ${ }^{[1]}$, 为深人解析土地利用对交通事故 的作用机制提供了途径。本文基于现有关于土地
利用与交通系统的文献,尝试运用交通四阶段模型 从出行行为视角揭示土地利用对交通事故的潜在 作用机理(图 3)。在该模型中, 土地利用是影响前三 阶段一一交通生成、交通分布、出行方式选择的主 要因素, 对出行行为的时间、长度、频率和方式等具 有重要作用 ${ }^{[62]}$, 进而可能对交通事故的类型和时空 分布产生重要影响。

\subsection{1 交通生成阶段}

首先, 土地利用作为城市功能的集中体现, 在 塑造城市人口和就业分布 ${ }^{[6]}$ 、设施可达性 ${ }^{[6]}$ 等方面 发挥着重要作用, 进而影响城市居民活动, 并决定 交通出行的产生、吸引与需求 ${ }^{[35]}$ 。由于不同用地功 能所承载的家庭数、就业岗位数存在差异, 导致所

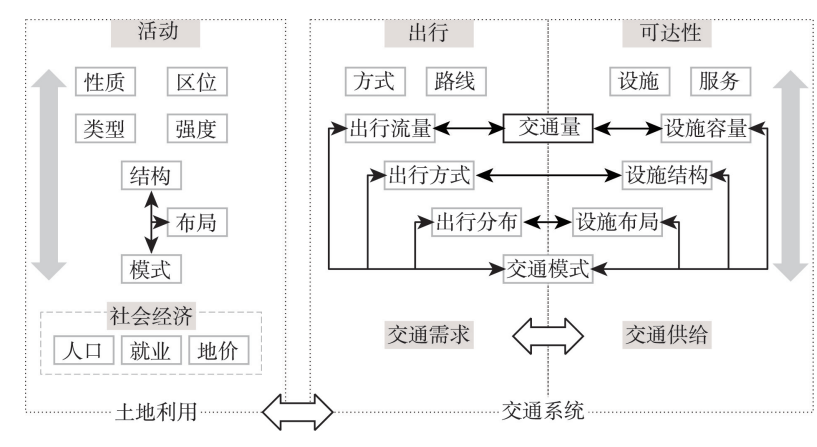

图 2 城市土地利用与交通系统的要素关联框架 ${ }^{[63]}$

Fig.2 A theoretical framework of the relationship between land use and transport system ${ }^{[63]}$

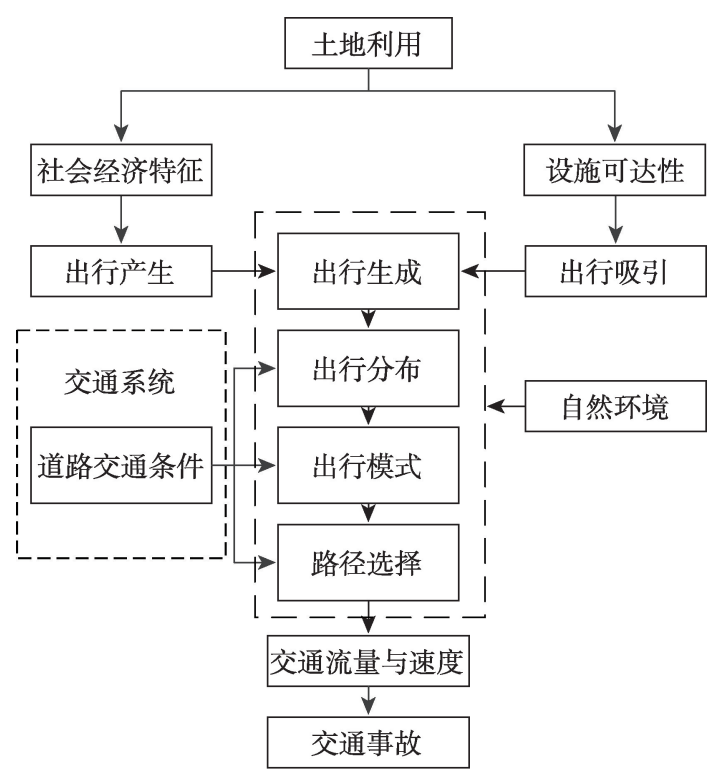

图 3 出行行为视角下城市土地利用对交通事故 作用机理的概念框架

Fig.3 A conceptual framework of the mechanism of land use impact on traffic accidents from the perspective of travel behavior 
形成的交通出行的产生和吸引量不同 ${ }^{[6]}$ 。土地使 用强度也是决定出行行为的主要因素之一 ${ }^{[67]}$, 高密 度的土地利用模式能够减少出行距离 ${ }^{[40]}$ 。此外, 土 地利用混合的区域,交通出行集中在区域内部,减 少了区域外的交通出行, 从而降低了城市总体的交 通出行里程和交通流量 ${ }^{[6]}$ 。总体而言, 城市土地利 用的功能、强度和模式等特征带来交通流向与强度 的差异性,进而可能导致交通事故的空间异质性。

\subsection{2 交通分布阶段}

交通分布是交通生成阶段所形成的出行流在 空间与时间上的具体体现。从时空角度来看, 不同 性质用地具有不同的时空出行特征, 依据出行的起 论点及出行的时段, 城市用地可划分为潮汐型、随 机型与集中型 ${ }^{[6]}$ 。依据工作时间, 城市用地可划分 为工作时间用地和非工作时间用地，而且工作时间 居住用地和零售商业用地的行人交通事故风险更 高 ${ }^{[69]}$ 。其次, 城市形态通过影响出行选择改变了区 域的出行分布, 例如土地利用形态的多样性能够促 使居民改变目的地,带来出行的内部化 ${ }^{[70]}$ 。此外, 城市扩张强度、城市群一体化发展与交通路网通达 性紧密相关 ${ }^{[71-72]}$, 城市用地布局形态更新影响城市 道路网的空间分布 ${ }^{[73]}$, 进而带来出行分布的变化。 因此,城市用地布局带来了交通出行行为分布的差 异性, 导致交通流量的时空聚集和分散, 可能使得 交通事故具有时空依赖性。

\subsection{3 出行方式选择阶段}

土地利用对出行方式选择具有显著影响 ${ }^{[7]}$ 。 首先, 不同土地利用类型的出行偏好存在差异 ${ }^{[75]}$ 。 以中国城市为背景的研究表明,一般住宅用地的非 机动化出行较多, 公共设施用地的公共交通出行较 多, 商务服务设施用地的小汽车出行比例则相对较 高 ${ }^{[6]}$ 。此外, 更多学者关注了土地利用模式对出行 方式的塑造作用。Cervero 等 ${ }^{[76]}$ 首次提出的“3D”理 论框架, 系统性地阐述了城市密度(density)、土地利 用多样性(diversity)、城市设计(design)对于出行行 为的影响, 在此基础上城市土地利用模式与出行方 式选择之间的关系得到了广泛的研究。例如, 高强 度混合开发的土地利用模式减少了平均出行距离, 从而有助于降低机动车出行频率和出行里程 ${ }^{[77-78]}$, 紧凑的土地利用模式会促进非机动车出行 ${ }^{[79]}$, 多中 心、集约、混合的土地利用模式能够减少出行距离、 出行时间和小汽车的使用 ${ }^{[00-81]}$, 且不同城市用地结 构会带来居民出行模式的变化 ${ }^{[82]}$; 反之, 分散的土
地利用模式会导致出行距离的被迫增加, 以及对于 小汽车出行的依赖 ${ }^{[83]}$ 。总体而言,城市出行区域的 土地利用类型和模式对居民出行方式具有重要影 响,可能导致交通事故的类型多样性。

\section{3 土地利用视角下交通事故的调控 研究}

从区域层面干预交通事故,紧凑发展是减少机 动车出行里程、降低交通事故率的最佳途径 ${ }^{[42]}$ 。为 实现这一目标, 不仅需要实现以公共交通为导向的 土地利用高密度发展 ${ }^{[10]}$, 而且还要注重土地利用结 构的平衡发展, 以此完善道路交通网络, 减少短距离 出行和交通拥堵, 降低交通事故率 ${ }^{[35]}$ 和严重程度 ${ }^{[47]}$ 。 针对不同类型用地对交通事故影响的差异性,在用 地布局中充分考虑交通安全是降低交通事故率的 主要手段之一。例如, 为降低学校周边的交通事故 率, 应避免布置商业用地以减少学校附近的交通流 量 ${ }^{[34]}$ 。土地利用模式方面, 为降低用地混合带来的 交通流量与交通事故增加的风险,需要在土地混合 利用的区域降低车速、优化道路设计 ${ }^{[44]}$; 而且, 居 住、商业与商住混合用地具有重大交通事故暴露的 高风险,在用地布局中应当避免将这 3 类用地集中 布置, 以减少交通流量的大规模混合增长 ${ }^{[58]}$ 。

其次, 基于土地利用优化的出行行为调控是降 低机动车与行人交通事故发生率与严重程度的重 要手段 ${ }^{[29]}$ 。通过合理的用地布局提高街道密度、鼓 励步行 ${ }^{[47]}$, 以及优化用地可达性、缩短出行生成和 出行吸引的距离能够减少小汽车出行 ${ }^{[69]}$, 从而大幅 度降低交通事故率。同时, 高密度、公交与步行导 向的土地混合模式, 能够减少出行距离, 增加步行、 自行车等积极出行方式的使用量 ${ }^{[8-85]}$ 。中国传统街 区采用密集街道网络与土地混合利用模式,也有利 于促进短距离出行和选择非机动化出行方式 ${ }^{[86]}$ 。此 外, 优化城市人口密度、职住平衡与道路连通性 ${ }^{[59]}$, 以及通过优化公交站点、道路交叉口设计等措施改 善交通条件与交通网络 ${ }^{[22]}$, 也是配套土地利用规划 改善城市交通安全的重要手段。

\section{4 结论与展望}

综上所述,城市土地利用对交通事故的驱动机 
理研究呈现出学科交融化、尺度微观化和视角多元 化特征。首先, 城市交通事故的影响因素具有多样 性和复杂性特点, 研究领域涉及地理学、交通工程 学、城乡规划学和公共卫生学等多个学科领域, 涉 及的影响因素包括社会经济环境、个体条件、自然 环境和建成环境等多方面。土地利用作为重要的 影响因素之一, 宏观层面主要探讨土地利用的形态 与模式对交通事故发生率的影响, 微观层面主要关 注城市土地利用类型和强度的差异性带来交通事 故的类型多样性和空间异质性。在此基础上开展 的城市土地利用对交通事故的作用机理研究,初步 形成了“土地利用一交通流量和交通速度一交通事 故” 的理论框架。关于不同类型交通事故的驱动机 理, 交通流量和交通速度发挥的中介作用和影响程 度则呈现差异性。当前, 从出行行为视角开展土地 利用对交通事故的影响研究还处在起步阶段, 主要 从微观层面探讨了土地利用与交通需求的关系及 其对交通事故的潜在影响, 对于进一步完善交通事 故的驱动机理具有重要的理论意义。

然而, 现有土地利用视角下的交通事故驱动机 理研究虽然解释了一般作用机理, 但仍无法精细表 征城市土地利用对交通需求及其所产生的交通流 量时空分布和出行方式的影响, 导致交通事故驱动 机理略显单一, 以此为基础制定的规划措施难以有 效调控交通事故风险。具体而言, 主要存在以下问 题: 首先, 关于土地利用特征往往从功能结构角度 (类型、强度、形态和模式) 展开分析, 忽略了城市用 地的出行行为特征对交通事故的重要影响, 导致交 通事故驱动机理研究结论的单一性; 其次, 现有研 究主要将交通流量与速度作为中介变量, 而交通流 量往往以出行里程测算而未考虑交通出行的流动, 忽视了出行行为是联系土地利用与交通流量的关 键环节, 即缺少从出行行为视角研究土地利用是如 何影响交通流量的生成和分布进而作用于交通事 故的过程, 并未考虑到土地利用对出行方式的影响 所带来的交通事故类型的差异性; 此外, 现有研究 侧重于构建模型分析城市土地利用与交通事故的 关系, 从实践层面探讨主动干预交通事故的土地利 用模式还较为欠缺。如何从出行行为视角探讨城 市土地利用与交通需求的关系, 进而深人解析城市 土地利用对交通事故的作用机理, 并以此为基础构 建一套交通安全导向的城市土地利用模式仍有待 进一步研究。
出行行为的多维属性特征是影响区域性交通 事故的关键因素。未来土地利用视角下的交通安 全研究,需要从出行行为视角分析城市土地利用与 交通系统的关系, 有助于识别交通流量、出行方式 等交通事故中介变量的时空分布特征以及城市用 地的出行行为特征, 进而深人刻画城市土地利用对 交通事故的作用机理,使交通事故的驱动机理回归 出行行为视角, 丰富和完善城市土地利用与交通事 故关系研究的理论体系。同时,未来研究需要着力 探索交通安全导向的城市土地利用模式与规划策 略, 围绕交通安全实现城市土地利用与交通系统的 多层次联动与有序重构,为优化城市土地利用和调 控交通事故风险提供决策支持。

\section{参考文献(References)}

[1] Giles-Corti B, Vernez-Moudon A, Reis R, et al. City planning and population health: A global challenge [J]. Lancet, 2016, 388: 2912-2924.

[2] Stevenson M, Thompson J, de Sa T H, et al. Land use, transport, and population health: Estimating the health benefits of compact cities [J]. Lancet, 2016, 388: 2925 2935.

[3] World Health Organization. Global status report on road safety 2015 [M]. Geneva, Switzerland: WHO Press, 2015: 285-286.

[4] 贺宜, 杨金炜, 吴兵, 等. 中美交通事故数据统计方法比 较研究 [J]. 交通信息与安全, 2018, 36(1): 1-9. [He Yi, Yang Xinwei, Wu Bing, et al. A comparative study on statistical methods of traffic accident data between China and the United States. Journal of Transport Information and Safety, 2018, 36(1): 1-9. ]

[5] Sallis J F, Bull F, Burdett R, et al. Use of science to guide city planning policy and practice: How to achieve healthy and sustainable future cities [J]. Lancet, 2016, 388: 29362947.

[6] 王新军, 王学斌, 信欣. 城市居民通勤、用地布局与交通 拥堵: 基于片区尺度的实证研究 [J]. 复旦学报(自然科 学版), 2018, 57(2): 199-204. [Wang Xinjun, Wang Xuebin, Xin Xin. Urban residents commuting, land use layout and traffic congestion: An empirical study based on area scale. Journal of Fudan University (Natural Science), 2018, 57(2): 199-204. ]

[7] Zou W, Wang X, Zhang D. Truck crash severity in New York city: An investigation of the spatial and the time of day effects [J]. Accident Analysis and Prevention, 2017, 99(8): 249-261. 
[8] Dumbaugh E, Li W. Designing for the safety of pedestrians, cyclists, and motorists in urban environments $[\mathrm{J}]$. Journal of the American Planning Association, 2011, 77 (1): 69-88.

[9] Aguero-Valverde J, Jovanis P. Spatial analysis of fatal and injury crashes in Pennsylvania [J]. Accident Analysis and Prevention, 2006, 38(3): 618-625.

[10] Wier M, Weintraub J, Humphreys E H, et al. An area-level model of vehicle-pedestrian injury collisions with implications for land use and transportation planning $[\mathrm{J}]$. Accident Analysis and Prevention, 2009, 41(1): 137-145.

[11] Noland R B, Quddus M A. A spatially disaggregate analysis of road casualties in England [J]. Accident Analysis and Prevention, 2004, 36(6): 973-984.

[12] Narayanamoorthy S, Paleti R, Bhat C R. On accommodating spatial dependence in bicycle and pedestrian injury counts by severity level [J]. Transportation Research Part B-Methodological, 2013, 55(6): 245-264.

[13] Siddiqui C, Abdel-Aty M, Choi K. Macroscopic spatial analysis of pedestrian and bicycle crashes [J]. Accident Analysis and Prevention, 2012, 45(3): 382-391.

[14] Anarkooli A J, Hosseinpour M, Kardar A. Investigation of factors affecting the injury severity of single-vehicle rollover crashes: A random- effects generalized ordered probit model $[\mathrm{J}]$. Accident Analysis and Prevention, 2017, 106(5): 399-410.

[15] Chen P, Shen Q. Built environment effects on cyclist injury severity in automobile-involved bicycle crashes [J]. Accident Analysis and Prevention, 2016, 86(11): 239-246.

[16] ChikkaKrishna N K, Parida M, Jain S S. Identifying safety factors associated with crash frequency and severity on nonurban four-lane highway stretch in India [J]. Journal of Transportation Safety \& Security, 2017, 9(1): 6-32.

[17] 陆荣杰, 张宁, 陈恺, 等. 美国出人口管理策略: 聚集城 市土地开发与交通 [J]. 城市交通, 2008, 6(4): 71-76. [Lu Rongjie, Zhang Ning, Chen Kai, et al. Access management: A focus of urban land development and transportation. Urban Transport of China, 2008, 6(4): 71-76. ]

[18] 丁微,徐铖铖,刘攀. 用地组合形态划分与交通安全影响 因素分析 [J]. 东南大学学报(自然科学版), 2017, 47(5): 1074-1078. [Ding Wei, Xu Chengcheng, Liu Pan. Classification of land-use combinations and analysis of influencing factors on traffic safety. Journal of Southeast University (Natural Science Edition), 2017, 47(5): 1074-1078. ]

[19] Aguero-Valverde J. Multivariate spatial models of excess crash frequency at area level: Case of Costa Rica [J]. Accident Analysis and Prevention, 2013, 59(6): 365-373.

[20] Huang H, Abdel-Aty M A, Darwiche A L. County-level crash risk analysis in Florida: Bayesian spatial modeling [J]. Transportation Research Record, 2010, 2148(4): 27-37.

[21] Ukkusuri S, Miranda-Moreno L F, Ramadurai G, et al. The role of built environment on pedestrian crash frequency [J]. Safety Science, 2012, 50(4): 1141-1151.

[22] De Guevara F L, Washington S P, Oh J. Forecasting crashes at the planning level: Simultaneous negative binomial crash model applied in Tucson, Arizona [J]. Transportation Research Record, 2004, 1897(1): 191-199.

[23] Lee J, Abdel-Aty M, Jiang X. Development of zone system for macro-level traffic safety analysis [J]. Journal of Transport Geography, 2014, 38(4): 13-21.

[24] 柳林,宋广文, 周素红, 等. 城市空间结构对惠州市中心 城区交通事故影响的时间差异分析 [J]. 地理科学, 2015, 35(1): 75- 83. [Liu Lin, Song Guangwen, Zhou Suhong, et al. Analysis on the time difference of the influence of urban spatial structure on traffic accidents in the central district of Huizhou. Scientia Geographica Sinica, 2015, 35(1): 75-83. ]

[25] Jiao J , Moudon A V, Li Y. Locations with frequent pedestrian- vehicle collisions: Their transportation and neighborhood environment characteristics in Seattle and King County, Washington [M]// Geertman S, Toppen F, Stillwell J. Planning support systems for sustainable urban development. Lecture notes in Geoinformation and Cartography, Vol 195. Berlin, Heidelberg, Germany: Springer, 2013: 281-296.

[26] Yamashita, Kim K, Pant P. Accidents and accessibility: Measuring the influences of demographic and land use variables in Honolulu, Hawaii [J]. Transportation Research Record, 2010, 2147(2): 9-17.

[27] Zahabi S A H, Strauss J, Manaugh K, et al. Estimating potential effect of speed limits, built environment, and other factors on severity of pedestrian and cyclist injuries in crashes [J]. Transportation Research Record, 2011, 2247(1): 81-90.

[28] Lee J, Abdel-Aty M. Macro-level analysis of bicycle safety: Focusing on the characteristics of both crash location and residence $[\mathrm{J}]$. International Journal of Sustainable Transportation, 2018, 12(8): 553-560.

[29] Moudon A V, Lin L, Jiao J, et al. The risk of pedestrian injury and fatality in collisions with motor vehicles, a social ecological study of state routes and city streets in King County, Washington [J]. Accident Analysis and Prevention, 2011, 43(1): 11-24.

[30] Yang B Z, Loo B P Y. Land use and traffic collisions: A link-attribute analysis using Empirical Bayes method [J]. Accident Analysis and Prevention, 2016, 95(7): 236-249. 
[31] Izanloo A, Rafsanjani A K, Ebrahimi S P. Effect of commercial land use and accessibility factor on traffic flow in bojnourd [J]. Journal of Urban Planning and Development, 2017, 143(2): 5016016. doi: 10.1061/(ASCE) UP.1943-5444.0000366.

[32] Miranda-Moreno L F, Morency P, El-Geneidy A M. The link between built environment, pedestrian activity and pedestrian- vehicle collision occurrence at signalized intersections [J]. Accident Analysis and Prevention, 2011, 43(5): 1624-1634.

[33] Osama A, Sayed T. Macro-spatial approach for evaluating the impact of socio-economics, land use, built environment, and road facility on pedestrian safety [J]. Canadian Journal of Civil Engineering, 2017, 44(12): 10361044.

[34] Yu C, Zhu X. Planning for safe schools: Impacts of school siting and surrounding environments on traffic safety [J]. Journal of Planning Education and Research, 2016, 36(4): 476-486.

[35] Pulugurtha S S, Duddu V R, Kotagiri Y. Traffic analysis zone level crash estimation models based on land use characteristics $[\mathrm{J}]$. Accident Analysis and Prevention, 2013, 50(6): 678-687.

[36] Kim K, Yamashita E. Motor vehicle crashes and land use: Empirical analysis from Hawaii [J]. Transportation Research Record, 2002, 1784(10): 73-79.

[37] Wang X, Yuan J, Schultz G G, et al. Investigating the safety impact of roadway network features of suburban arterials in Shanghai [J]. Accident Analysis and Prevention, 2018, 113(1): 137-148.

[38] Zhang M. The role of land use in travel mode choice: Evidence from Boston and Hong Kong [J]. Journal of the American Planning Association, 2004, 70(3): 344-360.

[39] Frumkin H. Urban sprawl and public health [J]. Public Health Reports, 2002, 117(3): 201-217.

[40] Dieleman F M, Dijst M, Burghouwt G. Urban form and travel behaviour: Micro- level household attributes and residential context [J]. Urban Studies, 2002, 39(3): 507527.

[41] Ewing R, Hamidi S. Urban sprawl as a risk factor in motor vehicle occupant and pedestrian fatalities update and refinement [J]. Transportation Research Record, 2014, 2513(5): 40-47.

[42] Ewing R, Hamidi S, Grace J B. Urban sprawl as a risk factor in motor vehicle crashes [J]. Urban Studies, 2016, 53(2): 247-266.

[43] Ewing R, Schieber R A, Zegeer C V. Urban sprawl as a risk factor in motor vehicle occupant and pedestrian fatal- ities [J]. American Journal of Public Health, 2003, 93(9): 1541-1545

[44] Chen P. Built environment factors in explaining the automobile-involved bicycle crash frequencies: A spatial statistic approach [J]. Safety Science, 2015, 79(6): 336-343.

[45] Amoh-Gyimah R, Saberi M, Sarvi M. Macroscopic modeling of pedestrian and bicycle crashes: A cross-comparison of estimation methods [J]. Accident Analysis and Prevention, 2016, 93(5): 147-159.

[46] Soltani A, Askari S. Exploring spatial autocorrelation of traffic crashes based on severity [J]. Injury, 2017, 48(3): 637-647.

[47] Wang Y, Kockelman K M. A Poisson-lognormal conditional-autoregressive model for multivariate spatial analysis of pedestrian crash counts across neighborhoods [J]. Accident Analysis and Prevention, 2013, 60(7): 71-84.

[48] Ewing R, Dumbaugh E. The built environment and traffic safety a review of empirical evidence $[\mathrm{J}]$. Journal of Planning Literature, 2009, 23(4): 347-367.

[49] Lee J S, Zegras P C, Ben-Joseph E. Safely active mobility for urban baby boomers: The role of neighborhood design [J]. Accident Analysis and Prevention, 2013, 61(5): 153-166.

[50] Lovegrove G R, Sayed T. Macro-level collision prediction models for evaluating neighbourhood traffic safety [J]. Canadian Journal of Civil Engineering, 2006, 33(5): 609-621.

[51] 杨奎, 余荣杰, 王雪松. 基于车道集计交通流数据的事 故风险评估分析 [J]. 同济大学学报(自然科学版), 2016, 44(10): 1567-1572. [Yang Kui, Yu Rongjie, Wang Xuesong. Accident risk assessment and analysis based on lane set traffic flow data. Journal of Tongji University (Natural Science), 2016, 44(10): 1567-1572. ]

[52] Chakraborty A, Mukherjee D, Mitra S. Development of pedestrian crash prediction model for a developing country using artificial neural network [J]. International Journal of Injury Control and Safety Promotion, 2019, 26(3): 283-293.

[53] Verzosa N, Miles R. Severity of road crashes involving pedestrians in Metro Manila, Philippines [J]. Accident Analysis and Prevention, 2016, 94(6): 216-226.

[54] Priyadarshini P, Mitra S. Investigating pedestrian risk factors leading to pedestrian fatalities in Kolkata City roads [J]. Transportation in Developing Economies, 2018, 4 (11): 1-11.

[55] Chen P, Zhou J. Effects of the built environment on automobile-involved pedestrian crash frequency and risk [J]. Journal of Transport \& Health, 2016, 3(4): 448-456. 
[56] Kamel M B, Sayed T, Osama A. Accounting for mediation in cyclist-vehicle crash models: A Bayesian mediation analysis approach [J]. Accident Analysis and Prevention, 2019, 131(7): 122-130.

[57] Guo Y, Ahmed O, Tarek S. A cross-comparison of different techniques for modeling macro- level cyclist crashes [J]. Accident Analysis and Prevention, 2018, 113(1): 38-46.

[58] Xie B, An Z, Zheng Y, et al. Incorporating transportation safety into land use planning: Pre-assessment of land use conversion effects on severe crashes in urban China [J]. Applied Geography, 2019, 103(12): 1-11.

[59] Najaf P, Thill J, Zhang W, et al. City-level urban form and traffic safety: A structural equation modeling analysis of direct and indirect effects [J]. Journal of Transport Geography, 2018, 69(5): 257-270.

[60] Dumbaugh E. Safe streets, livable streets [J]. Journal of the American Planning Association, 2005, 71(3): 283298.

[61] 易汉文. 城市用地分析与交通预测模型系统概述 [J]. 城市交通, 2006, 4(5): 55-62. [Yi Hanwen. General description of land- use and transportation modeling systems. Urban Transport of China, 2006, 4(5): 55-62. ]

[62] Zhang W, Zhang M. Incorporating land use and pricing policies for reducing car dependence: Analytical framework and empirical evidence [J]. Urban Studies, 2018, 55 (13): 3012-3033.

[63] 吴兵, 李林波, 王艳丽. 城市用地再开发与交通拥挤治 理策略 [M]. 上海: 同济大学出版社, 2017: 42-43. [Wu Bing, Li linbo, Wang Yanli. Urban land redevelopment and traffic congestion management strategies. Shanghai, China: Tongji University Press, 2017: 42-43. ]

[64] Lu J, Guldmann J. Employment distribution and land-use structure in the metropolitan area of Columbus, Ohio [J]. Journal of Urban Planning and Development, 2015, 141(4): 40140404. doi: 10.1061/(ASCE)UP.1943-5444.0000234.

[65] van Wee B. Evaluating the impact of land use on travel behaviour: The environment versus accessibility [J]. Journal of Transport Geography, 2011, 19(6): 1530-1533.

[66] 王艳丽, 李林波, 易军伟, 等. 基于交通需求的城市用地 分类方法 [J]. 重庆交通大学学报(自然科学版), 2013, 32(5): 995-1001. [Wang Yanli, Li Linbo, Yi Junwei, et al. Urban land use classification method based on traffic demand. Journal of Chongqing Jiaotong University (Natural Science), 2013, 32(5): 995-1001. ]

[67] 易汉文, 托马斯 - E - 莫里纳兹. 城市用地开发交通影响 分析的模式与模型 [J]. 城市交通, 2004, 2(1): 56-62. [Yi Hanwen, Mulinazzi T E. Mehtods and models for site impact traffic evaluation. Transport of China, 2004, 2(1):
56-62. ]

[68] Ewing R, Greenwald M, Zhang M, et al. Traffic generated by mixed-use developments: Six-region study using consistent built environmental measures [J]. Journal of Urban Planning and Development, 2011, 137(3): 248-261.

[69] Wedagama D M P, Bird R N, Metcalfe A V. The influence of urban land-use on non-motorised transport casualties [J]. Accident Analysis and Prevention, 2006, 38(6): 1049-1057.

[70] Greenwald M J. The relationship between land use and intrazonal trip making behaviors: Evidence and implications $[\mathrm{J}]$. Transportation Research Part D: Transport and Environment, 2006, 11(6): 432-446.

[71] 焦利民, 唐欣, 刘小平. 城市群视角下空间联系与城市 扩张的关联分析 [J]. 地理科学进展, 2016, 35(10): 1177-1185. [Jiao Limin, Tang Xin, Liu Xiaoping. Spatial linkage and urban expansion: An urban agglomeration perspective. Progress in Geography, 2016, 35(10): 11771185. ]

[72] 关兴良, 萄雪芹, 胡仕林, 等. 武汉城市群交通运输体系 与城镇空间扩展关联分析 [J]. 地理科学进展, 2014, 33 (5): 702-712. [Guan Xingliang, Lin Xueqin, Hu Shilin, et al. Relationship between transportation system and urban spatial expansion in Wuhan Urban Agglomeration. Progress in Geography, 2014, 33(5): 702-712. ]

[73] 李极恒, 龚岳, 李贵才. 珠三角村镇建成区的空间型态: 特征、类型和产业影响因素 [J]. 地理科学进展, 2019, 38(6): 829-839. [Li Jiheng, Gong Yue, Li Guicai. Spatial patterns of village and town built areas in the Pearl River Delta: A land- use perspective. Progress in Geography, 2019, 38(6): 829-839. ]

[74] Badoe D A, Miller E J. Transportation-land-use interaction: Empirical findings in North America, and their implications for modeling [J]. Transportation Research Part D: Transport and Environment, 2000, 5(4): 235-263.

[75] Boulange C, Gunn L, Giles-Corti B, et al. Examining associations between urban design attributes and transport mode choice for walking, cycling, public transport and private motor vehicle trips [J]. Journal of Transport \& Health, 2017, 6(8): 155-166.

[76] Cervero R, Kockelman K. Travel demand and the 3Ds: Density, diversity, and design [J]. Transportation Research Part D: Transport and Environment, 1997, 2(3): 199-219.

[77] Cervero R. Built environments and mode choice: Toward a normative framework [J]. Transportation Research Part D: Transport and Environment, 2002, 7(1): 265-284.

[78] Zhang M, Zhang W. When context meets self-selection: 
The built environment- travel connection revisited [J]. Journal of Planning Education and Research, 2018, 1(5): $1-16$.

[79] Dill J, Mohr C, Ma L. How can psychological theory help cities increase walking and bicycling? [J]. Journal of the American Planning Association, 2014, 80(1): 36-51.

[80] 孙斌栋, 但波. 上海城市建成环境对居民通勤方式选择 的影响 [J]. 地理学报, 2015, 70(10): 1664-1674. [Sun Bindong, Dan Bo. The influence of urban built-up environment in Shanghai on the choice of commuting mode of residents. Acta Geographica Sinica, 2015, 70(10): 1664-1674. ]

[81] 赵鹏军. 土地集约利用对可持续城市交通的作用: 基于 国际文献理论分析 [J]. 城市发展研究, 2018, 25(9): 108-116. [Zhao Pengjun. Effect of intensive land utilization on sustainable urban traffic: Analysis based on international literature theory. Urban Development Studies. Urban Development Studies, 2018, 25(9): 108-116. ]

[82] 王法辉, 刘瑜, 王姣娥. 交通网络与城市结构研究: 理论 框架与中美两国实证案例 [J]. 地理科学进展, 2014, 33 (10): 1289- 1299. [Wang Fahui, Liu Yu, Wang Jiao'e. Transport networks, intraurban structure and system of cities: A Sino- US comparative perspective. Progress in Geography, 2014, 33(10): 1289-1299. ]

[83] 周素红, 宋江宇, 宋广文. 广州市居民工作日小汽车出 行个体与社区双层影响机制 [J]. 地理学报, 2017, 72 (8): 1444- 1457. [Zhou Suhong, Song Jiangyu, Song Guangwen. The double- layer influence mechanism of Guangzhou residents working day car travel individual and community. Acta Geographica Sinica, 2017, 72(8): 1444-1457. ]

[84] Tabeshian M, Kattan L. Modeling nonmotorized travel demand at intersections in calgary, canada use of traffic counts and geographic information system data [J]. Transportation Research Record, 2014, 2430(1): 38-46.

[85] Kim T, Sohn D, Choo S. An analysis of the relationship between pedestrian traffic volumes and built environment around metro stations in Seoul [J]. KSCE Journal of Civil Engineering, 2017, 21(4): 1443-1452.

[86] 潘海啸, 沈青, 张明. 城市形态对居民出行的影响: 上海 实例研究 [J]. 城市交通, 2009, 7(6): 28-32. [Pan Haixiao, Shen Qing, Zhang Ming. Impacts of urban forms on travel behavior: Case studies in Shanghai. Urban Transport of China, 2009, 7(6): 28-32. ]

\title{
Research progress on the driving mechanism of traffic accidents from the perspective of land use
}

\author{
WANG Cheng, XIE Bo* \\ (School of Urban Design, Wuhan University, Wuhan 430072, China)
}

\begin{abstract}
Given the rapid urbanization and booming motor vehicle ownership in China, the existing land use and transport system are being widely reshaped, which have increasingly worsened the traffic safety situation. To optimize land use configuration and thus improve traffic safety, there is an urgent need to explore the driving mechanism of traffic accidents from the perspective of land use. The current literature generally supports the theoretical framework that traffic volume and traffic speed are major mediators associating land use with traffic accidents, while ignores that transport demand, which is derived from land use, plays a crucial role in shaping traffic accidents. Therefore, the association between land use, transport demand, and traffic accident is overlooked in exploring the driving mechanism of traffic accidents. This article reviewed existing studies by investigating the driving mechanism of traffic accidents from the perspective of land use based on influencing factor analysis, and summarized the future research directions. The results show that multi-dimensional land use attributes were strongly associated with the frequency of traffic accidents. Correspondingly, assessing the dynamic matching relationship between land use and transport system as well as its effects on travel behavior, would become particularly important in revealing the driving mechanism of traffic accidents. The corresponding findings could be used to support the construction of land use model for improving traffic safety.
\end{abstract}

Keywords: traffic accident; land use; driving mechanism; travel behavior 